\title{
Article \\ Insights of Raceway Bioreactor Scale-Up: Effect of Agitation on
Microalgae Culture and Reduction of the Liquid Medium Speed
}

Suri Sadai Bautista-Monroy ${ }^{1}$, Edgar Arturo Chávez-Urbiola ${ }^{2}{ }^{(0}$, Rocío Ortega-Palacios ${ }^{3}{ }^{\circledR}$, Armando González-Sánchez ${ }^{4}$, Carlos Alberto Gómez-Aldapa ${ }^{5}\left(\mathbb{D}\right.$, Odín Rodríguez-Nava ${ }^{6}$, Julio Cesar Salgado-Ramírez ${ }^{3, *(1)}$ and Arturo Cadena-Ramírez ${ }^{1, *}$

check for

updates

Citation: Bautista-Monroy, S.S.;

Chávez-Urbiola, E.A.;

Ortega-Palacios, R.;

González-Sánchez, A.;

Gómez-Aldapa, C.A.;

Rodríguez-Nava, O.;

Salgado-Ramírez, J.C.;

Cadena-Ramírez, A. Insights of

Raceway Bioreactor Scale-Up: Effect

of Agitation on Microalgae Culture

and Reduction of the Liquid Medium

Speed. Appl. Sci. 2022, 12, 1513

https://doi.org/10.3390/

app12031513

Academic Editor: Andreja Gorsek

Received: 15 December 2021

Accepted: 28 January 2022

Published: 30 January 2022

Publisher's Note: MDPI stays neutral with regard to jurisdictional claims in published maps and institutional affiliations.

Copyright: (c) 2022 by the authors. Licensee MDPI, Basel, Switzerland. This article is an open access article distributed under the terms and conditions of the Creative Commons Attribution (CC BY) license (https:// creativecommons.org/licenses/by/ $4.0 /)$.
1 Posgrado en Biotecnología, UPP, Carr. Pachuca-Cd. Sahagún, Km 20, Ex-Hacienda de Santa Bárbara, Zempoala C.P. 43830, Mexico; surimonroy@outlook.com

2 CONACyT-UAEH, ICBI. Carr. Pachuca-Tulancingo Km 4.5, Mineral de la Reforma, Pachuca C.P. 42184, Mexico; chavez.urbiola@gmail.com

3 Ingeniería Biomédica, UPP, Carr. Pachuca-Cd. Sahagún, Km 20, Ex-Hacienda de Santa Bárbara, Zempoala C.P. 43830, Mexico; rortega@upp.edu.mx

4 Instituto de Ingeniería, UNAM, Circuito Escolar, Ciudad Universitaria, Mexico City 04510, Mexico; agonzalezs@iingen.unam.mx

5 UAEH, ICBI. Carr. Pachuca-Tulancingo Km 4.5, Mineral de la Reforma, Pachuca C.P. 42184, Mexico; cgomeza@uaeh.edu.mx

6 ENCB, IPN, Wilfrido Massieu s/n, Unidad Profesional Adolfo López Mateos, Mexico City C.P. 07738, Mexico; crodriguezna@ipn.mx

* Correspondence: csalgado@upp.edu.mx (J.C.S.-R.); arturocadena@upp.edu.mx (A.C.-R.)

\begin{abstract}
The scaling of Raceway bioreactors was studied by geometric and mechanical similarity, with an order of magnitude of 1:10. The hydrodynamic parameters involved (flow velocity, hydrodynamic stress or shear stress, dimensionless numbers of Re, Fr, and Euler Power) at different stirring speeds $(30,35,40$, and $45 \mathrm{rpm})$ were determined. The study, carried out using low-density particle imaging velocimetry (PIV), showed that the speed of the liquid medium remains above $30 \mathrm{~cm} / \mathrm{s}$ from $30 \mathrm{rpm}$, which ensures turbulence in the system. The flow velocity suffers a decrease of approximately $18 \%$, at different angular velocities, with similar biomass concentrations $\left(3.24 \times 10^{5}-3.72 \times 10^{5}\right.$ cells $\left./ \mathrm{mL}\right)$. This decrease in speed directly affects the values of all the parameters involved in the bioreactor. Furthermore, the measurement of hydrodynamic stress $(\tau)$ indicates that the microorganisms are exposed to a value of $0.299 \mathrm{~Pa}$ at $35 \mathrm{rpm}$ and $0.370 \mathrm{~Pa}$ at $40 \mathrm{rpm}$. Due to mechanical agitation, hydrodynamic stress values in Raceway systems have not been previously reported. The studies were carried out in a $10 \mathrm{~L}$ Raceway bioreactor using a consortium of microalgae and cyanobacteria where Spirulina sp. and Pseudanabaena sp. predominate.
\end{abstract}

Keywords: raceway; scaling-up; hydrodynamic stress; microalgae consortium

\section{Introduction}

Today, the study of microalgae has grown exponentially because it has a wide field of applications, from biofuels to food products [1,2]. These microorganisms are cultivated mainly in Raceway bioreactors, which are open ponds with the shape of a circuit provided by mechanical agitation using a paddle wheel [3,4]. Even though Raceway bioreactors are the preferred culture systems for most of the industries dedicated to the cultivation of photosynthetic microorganisms [5,6], their scaling has been little studied in an analytical and experimental way. The greatest contributions to this process have been made thanks to computational analysis in simulators [7], and for this reason, there are scarce works that study the effects that scaling-up can cause on the cultivation of microalgae. The need for agitation is due to the requirement of the microalgae culture for exposure to light. The mixing avoids self-shading, which originates among the same microorganisms as the crop evolves. Additionally, adequate agitation ensures homogeneity in the values of 
$\mathrm{pH}$, temperature, carbon source and the other nutrients; it also avoids sedimentation of microorganisms [8]. Without agitation, a culture of high cell density cannot keep moving, leading to high agglomeration of microalgae [9]. However, not all microorganisms respond in the same way, some can reduce the size of cell aggregates [10].

There are countless studies that report the stress generated by mechanical agitation, known as hydrodynamic stress, is reflected in the growth rate and composition change of the biomass [10-12]. However, there are no studies of these effects in the Raceway bioreactors. Various studies have focused on the configuration of the mechanical stirrer used since it has been proven that the geometry directly influences the flow patterns in these bioreactors [13,14]. Bautista-Monroy et al. [15] tested four different agitator geometries vs. the flat blade agitator and reported that a 6 curved blade turbine type agitator provides better agitation than the conventional flat blade agitator. In the same sense, when a study is carried out to improve agitation and/or carry out a change of scale, it is necessary to carry out a hydrodynamic study. The hydrodynamic study considers several parameters. The most studied are the velocity profile and the flow regime, among others $[7,16]$. However, when microorganisms are involved in systems provided by mechanical agitation, it is necessary to study the hydrodynamic stress generated by the shear forces on the cells, either due to the scale of the vortices, the friction with the walls of the open pond, or the interaction with the stirrer $[10,17]$.

\section{Materials and Methods}

\subsection{Bioreactor Scaling-Up}

Dimensional analysis was performed for an incompressible, stationary fluid with a free surface, on which a few variables involved in the flow were determined. The dimensionless numbers involved in scaling were obtained from the Vaschy-Buckingham Pi theorem. In addition, the characteristic lengths of the pilot bioreactor were calculated, maintaining a geometric relationship (length/width) of 2.5 and a depth of $0.15 \mathrm{~m}$. The scaling-up was carried out in an order of magnitude of 1:10 in volume, so a $10 \mathrm{~L}$ laboratory bioreactor was scaled to a $100 \mathrm{~L}$ pilot. The hydrodynamic conditions to be scaled were evaluated in the laboratory bioreactor through dimensional analysis to verify the relationships between the two scales by geometric, dynamic, and kinematic similarity [18,19].

\subsection{Bioreactor and System Conditions}

To evaluate the hydrodynamic conditions to be scaled, the particle image velocimetry (PIV) methodology reported by Bautista-Monroy et al. [15] was used. A Raceway bioreactor $70 \mathrm{~cm}$ long by $20 \mathrm{~cm}$ wide and $8 \mathrm{~cm}$ deep was used [20]. To maintain controlled lighting conditions and avoid interference from natural light, a $100 \mathrm{~cm}$ long by $100 \mathrm{~cm}$ high darkroom was set up. It was illuminated with an ultraviolet light lamp (UVP of $6 \mathrm{~W}$ and $365 \mathrm{~nm}$ wavelength). Fluorescent particles were used to characterize the flow and determine the velocity. In the pilot Raceway bioreactor, velocity was determined by measuring the time it takes for a particle to travel the full length of the channels since, due to the size of the bioreactor, it is difficult to control the light and apply the PIV methodology. In both bioreactors, six angular stirring speeds were tested between 20 and $45 \mathrm{rpm}$.

\subsubsection{Abiotic Media}

To determine the hydrodynamic behavior in an abiotic medium, the PIV of medium particle density was used. Videos were taken (10 min at $120 \mathrm{fps}$, Sunco, 12-megapixel resolution) of the Raceway bioreactor with 20 tracer particles of sodium alginate and (sodium fluorescein). These particles have a diameter of $100 \mu \mathrm{m}$ and a density of $654 \mathrm{~kg} / \mathrm{m}^{3}$, which is similar to the cell density of some microalgae, such as Arthrospira maxima. These conditions ensure that the microspheres are carried away by the flow currents generated within the Raceway [15]. Stirring speeds of 20, 25, 30, 35, 40, and $45 \mathrm{rpm}$ were evaluated. The bioreactor is provided with a 6 curved blade turbine-type mechanical agitator $[8,15]$. Ob- 
taining the images was through video capture. To determine the flow velocity, Equation (1) was used:

$$
\frac{d x}{d t}=k v
$$

where $k$ is a conversion factor from pixels to meters. From the speed, the Reynolds number of the channel was calculated with Equation (2) and the Reynolds number in the stirrer, Equation (3):

$$
\begin{aligned}
N_{R e} & =\frac{\rho v d_{h}}{\mu} \\
N^{\prime}{ }_{R e} & =\frac{\rho N D_{a}^{2}}{\mu}
\end{aligned}
$$

In Raceway bioreactors, the effect of hydrodynamic stress is believed to be so low that it is generally neglected. Because of this, there are no equations to determine it analytically. This condition induces the measurement of hydrodynamic stress $(\tau)$, as a combination of channel effects including the wall and bottom, where it is estimated that the shear rate $\left(\gamma_{c}\right)$ is $4 \%$ of the average velocity on the channel. The effect of shear rate generated by the stirrer $\left(\gamma_{s}\right)$, hydrodynamic stress, was determined according to Equation (4):

$$
\tau=\mu \cdot\left(\gamma_{c}+\gamma_{s}\right)
$$

The shear rate in the agitator $\left(\mathrm{s}^{-1}\right)$ was determined by Equation (5)

$$
\gamma_{s}=N^{3 / 2}\left(\frac{4 N_{P} \rho d^{2}}{27 \pi \mu}\right)^{1 / 2}
$$

\subsubsection{Flow Patterns and Dead Zones}

To visualize the flow patterns and dead zones of the system, fluid paths were traced by PIV analysis of the bioreactor at three stirring speeds (35, 40, and $45 \mathrm{rpm}$ ) without microorganisms. The dead zones are quantified as a function of the volume fraction, where the flow velocity is less than $0.10 \mathrm{~m} / \mathrm{s}$ as defined by equation (6), where $\% d z$ represents the volume fraction of the dead zones, $V_{v}<0.1$ is the volume of fluid where the circulation velocity is less than $0.10 \mathrm{~m} / \mathrm{s}$, and $V_{t}$ is the working volume of the Raceway; the working volume depends on the area of the Raceway and the culture depth $[4,15]$.

$$
\begin{gathered}
\% d z=\frac{V_{v<0.1}}{V_{t}} \cdot 100 \\
V_{t}=A_{R} \cdot h \\
A_{R}=\pi \cdot w^{2}+\left(s \cdot R_{w}\right)
\end{gathered}
$$

\subsubsection{Speed Adjustment in Both Reactors}

To determine velocity and hydrodynamic parameter correspondences, tracer velocity data obtained by PIV was analyzed. This allowed for a full channel average velocity fit against angular velocity where the speed of the tracer was taken as the speed of the complete channel with respect to the angular speed of the rotor.

\subsubsection{Biotic Media}

For hydrodynamic characterization with microorganisms, a microalgae consortium was used, and the decrease in flow velocity with respect to biomass growth was determined. The consortium was donated by the National Autonomous University of Mexico and was isolated from Texcoco lake. It is composed of: Spirulina sp., Pseudanabaena sp., Microcystis sp., Chlorococcum sp., Nitzschia sp., Picochlorum sp. and a protozoan [21]. The microalgae were kept in flasks with modified Zarrouk medium [21] before being transferred to the pilot Raceway bioreactor. Growth kinematics were performed for 14 days with 
stirring speeds of 30-45 rpm in 5 rpm intervals. Throughout the culture, the initial speed, the reduction in speed with respect to cell growth, the Reynolds number in the channel and in the stirrer, as well as the hydrodynamic stress induced to the cells due to agitation were determined. Biomass growth was determined by cell counting with a Neubauer chamber until reaching the stationary phase [22]. Growth was determined in both bioreactors.

\section{Results}

\subsection{Raceway Bioreactor Scaling-Up}

The results of the dimensional analysis showed that the following magnitudes are involved: flow velocity, characteristic diameter, density, viscosity, gravitational acceleration, and surface tension. The following dimensionless numbers predominated: Reynolds $(R e)$, Froude $(F r)$, and Euler $(E u)$. Since the model-based scaling method used involves the effects of the bioreactor geometry on the hydrodynamic behavior [23,24], it is of utmost importance to maintain relations of gravitational, inertial, and viscous force relationships. However, it is often impossible to keep all dimensionless groups constant during scaling. Because of this, dimensional analysis helps to determine the most important groups [25]. With the application of the geometric similarity model, the dimensions of the pilot-scale bioreactor were obtained: $1.62 \mathrm{~m}$ long, $0.15 \mathrm{~m}$ deep, and $0.462 \mathrm{~m}$ wide (Figure 1). The Raceway is constructed of fiberglass, is provided with a stainless steel six curved blade turbine stirrer, and has a total capacity of $100 \mathrm{~L}$.

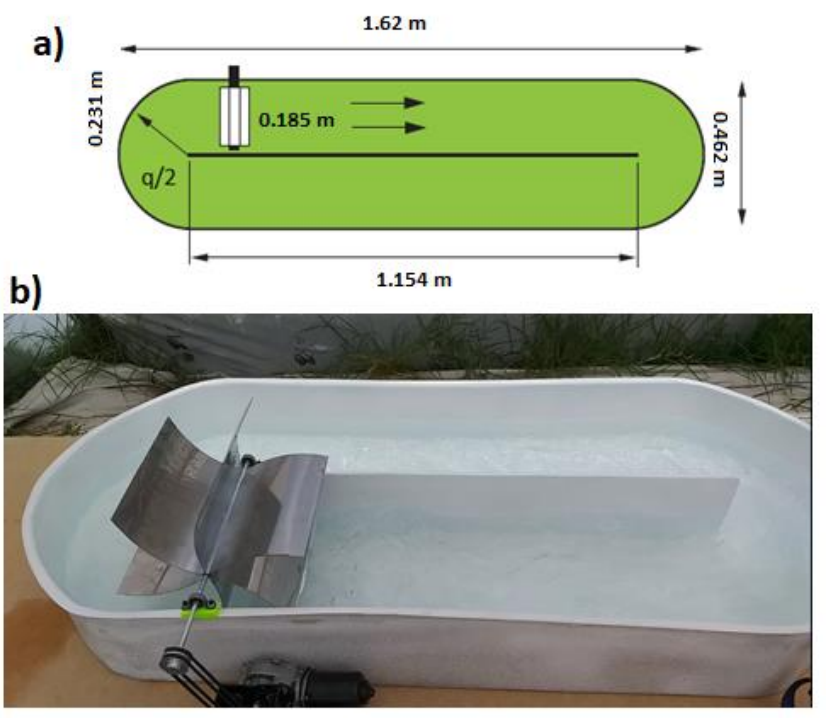

Figure 1. Pilot raceway bioreactor with agitation system. (a) Top view layout with raceway dimensions (b) 100 L raceway pilot unit.

Table 1 shows the experimental data of average velocities $(V)$ obtained in the Raceway bioreactor. Due to the nature of the system, the speed variations in the different sections are very pronounced. Therefore, the standard deviations were not considered.

Table 1. Hydrodynamic parameters in the laboratory Raceway bioreactor.

\begin{tabular}{cccccc}
\hline $\boldsymbol{\omega}(\mathbf{r p m})$ & $\boldsymbol{V}(\mathbf{m} / \mathbf{s})$ & $\boldsymbol{R} \boldsymbol{F}$ & $\boldsymbol{F r}$ & $\boldsymbol{R} \boldsymbol{e}^{\prime}$ & $\boldsymbol{\tau} \mathbf{( P a )}$ \\
\hline 20 & 0.2452 & 99.008 & 0.2858 & 205.251 & 0.1344 \\
25 & 0.2870 & 115.887 & 0.3345 & 256.564 & 0.1856 \\
30 & 0.3515 & 141.952 & 0.4098 & 307.877 & 0.2430 \\
35 & 0.4058 & 163.881 & 0.4731 & 359.190 & 0.3047 \\
40 & 0.4563 & 184.275 & 0.532 & 410.502 & 0.3707 \\
45 & 0.5068 & 201.669 & 0.5908 & 461.815 & 0.4408 \\
\hline
\end{tabular}


Depending on the speed and the geometric characteristics, hydrodynamic parameters were determined, such as: $R e$ and $F r$, Reynolds in the stirrer $\left(R e^{\prime}\right)$, as well as the hydrodynamic stress value $(\tau)$ that will influence the microalgae. Table 1 shows these values, where there are hydrodynamic stress values from 0.1344 to $0.4408 \mathrm{~Pa}$ that correspond to the values determined in the $10 \mathrm{~L}$ bioreactor.

When scaling involving dynamic and kinematic characteristics is performed, it is recommended to determine velocity correspondences in both systems [23]. Therefore, the speed correspondence was determined in both systems to verify that the scaling-up was carried out correctly. This correspondence $\left(V^{\prime}, V^{\prime \prime}\right)$ was carried out from 30 to $45 \mathrm{rpm}$, where it was found that, in all cases, the correspondence was close to unity (Table 2).

Table 2. Correspondence of linear velocities to different angular velocities.

\begin{tabular}{ccccc}
\hline$\omega(\mathbf{r p m})$ & $V_{\text {lab }}(\mathbf{m} / \mathbf{s})$ & $V_{\text {pil }}(\mathbf{m} / \mathbf{s})$ & $V^{\prime}($ pil/lab) & $V^{\prime \prime}(\mathbf{l a b} /$ pil) \\
\hline 30 & 0.3485 & 0.3515 & 1.0086 & 0.9915 \\
35 & 0.3949 & 0.4058 & 1.0276 & 0.9731 \\
40 & 0.4494 & 0.4563 & 1.0154 & 0.9849 \\
45 & 0.4903 & 0.5068 & 1.0337 & 0.9674 \\
\hline
\end{tabular}

Correspondence pilote/laboratory $\left(V^{\prime}\right)$; laboratory/pilote $\left(V^{\prime \prime}\right)$.

The velocity and correspondence values of the systems ensured that the behavior of the fluid in the pilot Raceway will be the same as the laboratory system. There are studies on medium and large-scale Raceway bioreactors, such as Chiaramonti et al. [26], which addressed a $20 \mathrm{~m}^{2}$ Raceway bioreactor, which maintains a varying work volume between 3000 and $4000 \mathrm{~L}$ and flow velocities between 0.15 and $0.25 \mathrm{~m} / \mathrm{s}$, in addition to a $500 \mathrm{~m}^{2}$ industrial Raceway bioreactor that maintains a flow velocity of $0.20 \mathrm{~m} / \mathrm{s}$. The previous speeds, contrasted with Table 1, correspond to a stirring of $20 \mathrm{rpm}$. This shows that the pilot bioreactor scaled-up in this project is comparable with larger bioreactors, even industrial ones.

\subsection{Speed Correlation}

The adjustment $\left(\mathrm{r}^{2}=0.985\right)$ suggests that the average speed in the channel can be established from the rotor speed using Equation (9):

$$
y=-0.001 x^{2}+0.0215 x-0.1906
$$

where $y$ is the average velocity of the channel $(\mathrm{m} / \mathrm{s})$, and $x$ is the angular velocity in rpm (Figure 2). This correlation equation allows making interpolations between 16 to $44 \mathrm{rpm}$ and extrapolations for rotor speeds of approximately 46 to $60 \mathrm{rpm}$.

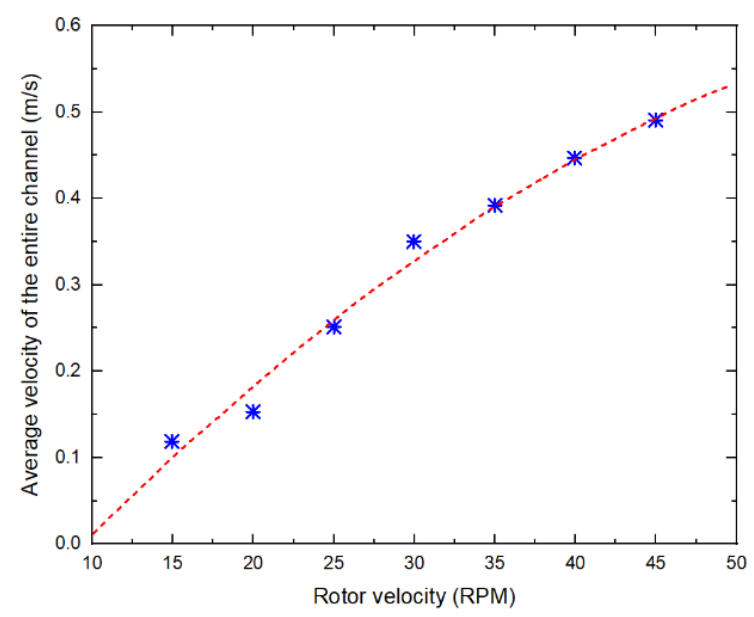

Figure 2. Correlation of average velocity vs. angular velocity; (*) Experimental Data, (---) Fitted model. 
The data presented diverge from those of Sompech et al. [7], which relates the velocity in $\mathrm{m} / \mathrm{s}$ of three different Raceway bioreactor configurations at 35, 40, and $45 \mathrm{rpm}$, these angular velocities produce flow velocities of $0.12,0.14$, and $0.19 \mathrm{~m} / \mathrm{s}$ correspondingly. Speeds, especially at $30 \mathrm{rpm}$, are very low and close to the speed limit that is considered part of the dead zones. From another point of view, the data shown in Figure 2 present speeds from 0.40 to $0.50 \mathrm{~m} / \mathrm{s}$ at stirring speeds from 35 to $45 \mathrm{rpm}$. This speed difference is associated with the configuration of the curved blade agitator and the geometric relationships that it maintains with respect to the dimensions of the Raceway since it ensures flow speeds that keep most of the bioreactor in turbulence, a condition that is favorable for microalgal growth [8].

Similarly, the relationship between the speed presented by the tracer on the walls of the Raceway was studied by adjusting the speeds next to the curved section vs. the straight section of the wall, but there was no model to explain the observed. Changing the approach, the distribution of velocities near the wall was analyzed and found to follow a gamma probability distribution (Figure 3). The statistical model explains both the speeds in the straight part and in the curve of the Raceway. With the parameters of the gamma function, the geometry of the Raceway bioreactor can be associated with the angular velocities, in this way, just by varying the parameters of the gamma function, the geometric parameters for Raceway of different sizes can be obtained, which could function as a different scaling-up method.

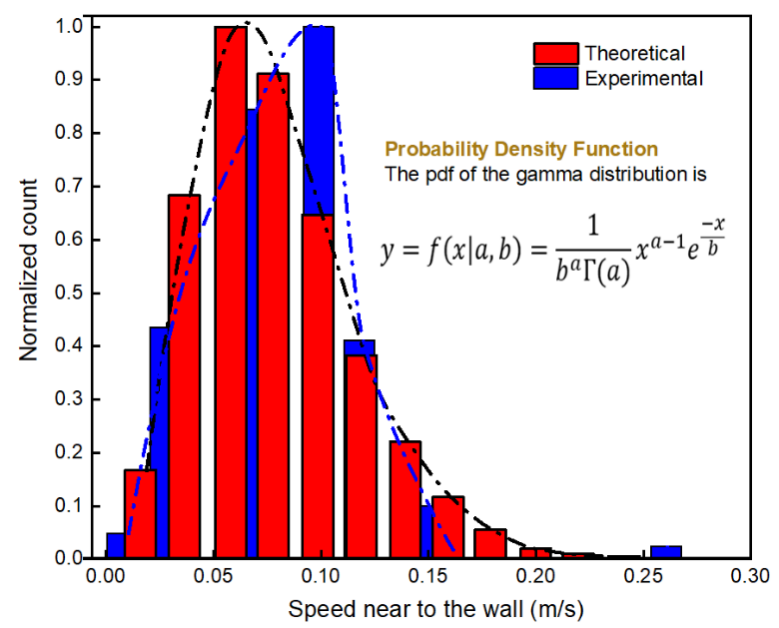

Figure 3. Probability distribution of velocities near the wall of the Raceway bioreactor; (---) Experimental pdf, (--) Theoretical pdf.

\subsection{Flow Patterns and Dead Agitation Zones}

In the microalgae cultivation, dead zones occur when the agitation speed is not sufficient, therefore, the liquid speed is low, which causes accumulation and cell death in these areas. In addition, the formation of toxic compounds occurs, as well as the development of anaerobic zones that produce the propagation of bacteria, conditions that lead to the loss of microalgae cultivation. Due to the above, the percentage of dead zones must be minimized $[14,16]$.

Figure 4 shows the increase in angular velocity and the paths followed by the tracer particles, which cover more and more areas of the system as rpm increases, causing a decrease in dead zones. Figure 4a shows that turbulence occurs at the agitator outlet, followed by a dead zone. The traced routes tend to stick to the walls of the system, leaving the area of the second curve free, where the dead zone with the largest area occurs. Figure $4 \mathrm{~b}$ represents the flow patterns at $40 \mathrm{rpm}$, where the traced routes reach the agitator's fluid suction zone more easily, which generates turbulence in the discharge, reducing the area of the dead zone. After the second corner, vortices are generated; however, the dead zone is not removed, but it does decrease. Figure $4 \mathrm{c}$ shows that, at a higher angular velocity, there is a greater distribution of the fluid and fewer dead zones. Linear, vortex, and annular flow 
patterns are observed, the latter being characteristic of turbulence. Despite this, the dead zones are not eliminated, especially after the stirrer, because the stirrer presents suction, even in the discharge zone $[8,15]$.

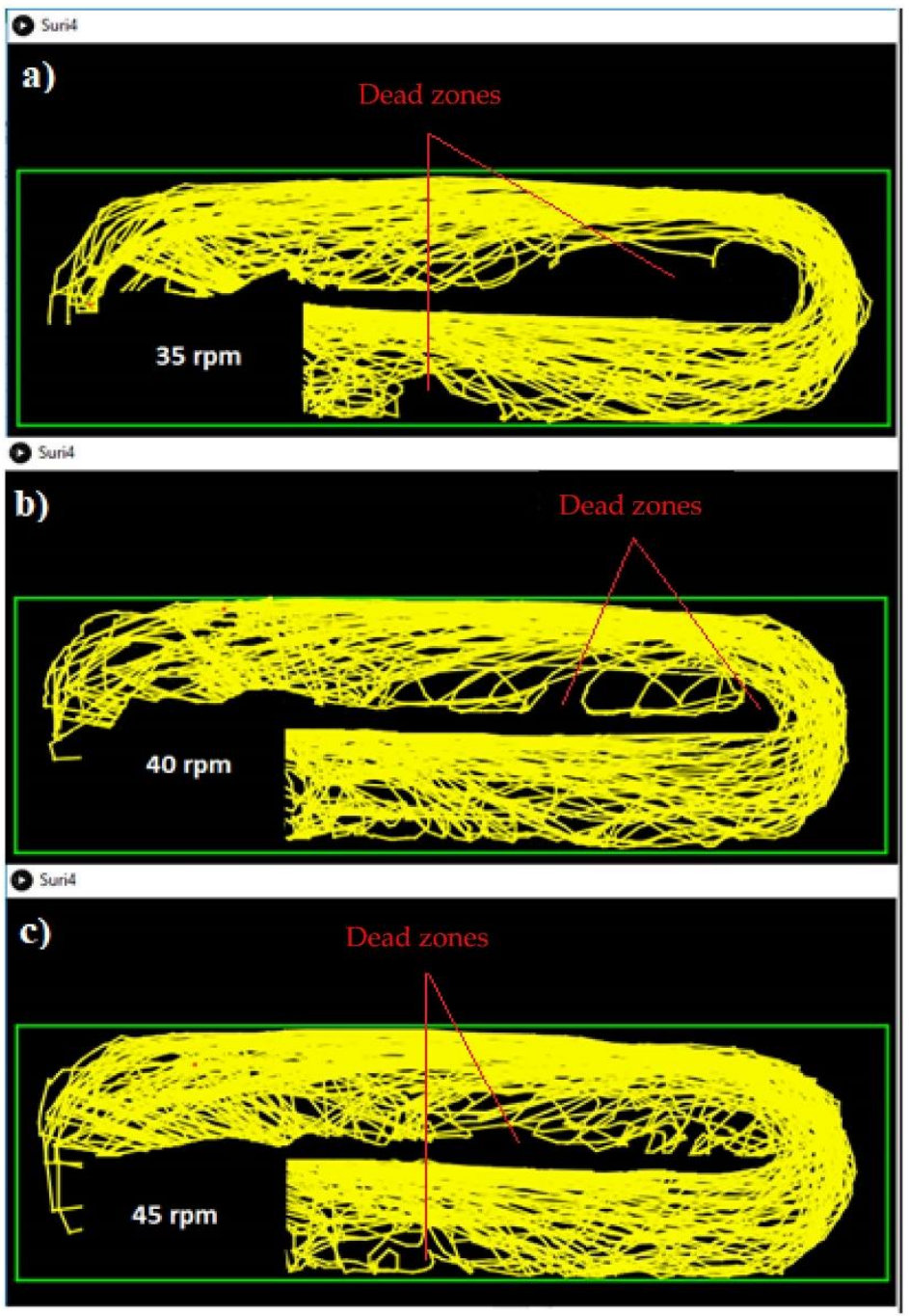

Figure 4. Flow patterns at different agitation speeds, it is observed that, by increasing the agitation speed, the presence of dead zones decreases. Flow pattern at (a) $35 \mathrm{rpm}$, (b) $40 \mathrm{rpm}$ (c) $45 \mathrm{rpm}$.

Agitation dead zones at the Raceway represent $13.48 \%, 7.93 \%$, and $4.61 \%$ at 35 , 40, and $45 \mathrm{rpm}$, respectively. These obtained values are like those of Bautista-Monroy et al. [15], where there was a reduction of $\% d z$, from $15.38 \%$ to $12.75 \%$ and $8.52 \%$, at stirring speeds of 20,25 , and $30 \mathrm{rpm}$, respectively. Although the value of $\% d z$ at 35 and $40 \mathrm{rpm}$ (Table 3) differs very little from the value reported by Bautista-Monroy et al. [15], it can be justified by the increase in fluid velocity and the centripetal and centrifugal forces that are exerted on the second curve of the bioreactor. While the centripetal force tries to keep the flow currents at the center of the curve, the centrifugal force is greater and causes the flow currents to open more to the curve, promoting the flow to follow paths close to the wall of the bioreactor curve. At $45 \mathrm{rpm}$, the \%dz shows a considerable decrease, having only $4.61 \%$ dead zones. These $\% d z$ values are comparable with those reported by Hadiyanto et al. [16], which reports a reduction of dead zones from $18 \%$ to a minimum of $3 \%$ by varying the aspect ratio of a Raceway bioreactor, maintaining flow velocity between $0.15-0.33 \mathrm{~m} / \mathrm{s}$ in a CFD simulation. 
Table 3. Hydrodynamic parameters in abiotic media.

\begin{tabular}{ccccccccccc}
\hline$\omega(\mathbf{r p m})$ & $\boldsymbol{v}(\mathbf{m} / \mathbf{s})$ & $v_{\text {tip }}(\mathbf{m} / \mathbf{s})$ & $E_{c a}(\mathrm{~J})$ & $\boldsymbol{R e}_{\boldsymbol{s t}}$ & $\boldsymbol{R} \boldsymbol{e}_{\boldsymbol{c h}}$ & $\boldsymbol{F r}$ & $\boldsymbol{P}(\mathbf{W})$ & $\boldsymbol{N}_{\boldsymbol{p}}$ & $\boldsymbol{\tau}(\mathbf{P a})$ & $\% d z$ \\
\hline 35 & 0.3949 & 0.3115 & $1.6618 \times 10^{-5}$ & 21,325 & 35,900 & 0.7974 & 0.4743 & 7.1489 & 0.3576 & 13.48 \\
40 & 0.4494 & 0.356 & $2.1705 \times 10^{-5}$ & 24,371 & 40,855 & 0.9075 & 0.542 & 5.4734 & 0.3834 & 7.93 \\
45 & 0.4903 & 0.4006 & $2.7470 \times 10^{-5}$ & 27,418 & 44,573 & 0.9901 & 0.6098 & 4.3247 & 0.4072 & 4.61 \\
\hline
\end{tabular}

In addition to the above, the hydrodynamic parameters in an abiotic medium were calculated to provide an approximation to the behavior of the fluid with the microorganisms in the Raceway bioreactor.

Table 3 shows the linear speed values $(v)$ at different stirring speeds $(\omega)$. The typical stirrer speed $\left(v_{t i p}\right)$ in $\mathrm{m} / \mathrm{s}$ was determined with Equation (10).

$$
v_{t i p}=r \omega\left(\frac{2 \pi}{60}\right)
$$

where $r$ is the radius of the agitator, from the axis, and $\omega$ is the angular velocity in rpm. The $v_{\text {tip }}$ is used to determine the cell-stirrer collision energy $\left(E_{c a}\right)$ with Equation (11).

$$
E_{c a}=\frac{1}{2}\left(\rho_{c} \frac{\pi}{6} d_{c}^{3}\right) \cdot v_{t i p}^{2}
$$

where $\rho_{c}$ and $d_{c}$ are the density and diameter of the cell, respectively [27]. In this case, the maximum $E_{c a}$ to which the microalgal cells will be exposed is estimated to be $1.6618 \times 10^{-5}$, $2.1705 \times 10^{-5}$, and $2.7470 \times 10^{-5} \mathrm{~J}$, at 35,40 , and $45 \mathrm{rpm}$, respectively. The collisions between the cells and the stirrer are those that cause the most damage to the culture since, in this area, there is greater turbulence, fluid velocity, and suction and discharge of the stirrer. It is important to note that in Raceway systems, this parameter has not been determined, so there are no values in the literature to compare. In contrast, García-Ochoa et al. [28] carried out cultures of Xanthomonas campestris under different hydrodynamic conditions in a stirred tank bioreactor, in which they reported $E_{c a}$ values of $1.3 \times 10^{16} \mathrm{~J}, 5.5 \times 10^{16} \mathrm{~J}$ and $16 \times 10^{16} \mathrm{~J}$ at typical stirrer speeds of $0.246 \mathrm{~m} / \mathrm{s}, 0.517 \mathrm{~m} / \mathrm{s}$, and $0.821 \mathrm{~m} / \mathrm{s}$ respectively. Although the geometric configuration of the bioreactor of García-Ochoa et al. [28] is different from that of the present study, the typical speeds of the stirrer are in a similar range (Table 3). The $E_{c a}$ values of the present work are much lower, which causes the cellular damage to be minimal. This is thanks to the sign of the curved agitator (turbine type), which decreases cavitation in the agitator zone when it drives the fluid, creating a laminar underlayer at the solid-liquid interface, which leads the cells to move parallel to the flow lines, as indicated Mazzuca [29].

The values of the parameters in Table 3 increase by the increase in angular velocity, except for the Power Number $\left(N_{P}\right)$, which decreases with increasing power consumption $(P)$. These values are expected to be the maximums presented in the cultivation of the microalgae consortium. In all cases, the Reynolds number corresponds to the turbulent regime in the stirrer $\left(R e_{s t}\right)$ and the channel $\left(R e_{c h}\right)$. The difference observed in these two zones is that the first depends on the annular velocity and the second on the flow velocity $[11,30]$. Sompech et al. [7] state that in the Raceway bioreactor, the flow remains turbulent with $\operatorname{Re}$ values $>1000$. However, this criterion is not always met since the Raceway bioreactor is composed of channels, and the flow in these can be considered laminar with Re values $<10,000$ [15]. On the other hand, the hydrodynamic stress $(\tau)$ was $0.3576,0.3834$, and $0.4072 \mathrm{~Pa}$ at 35,40 , and $45 \mathrm{rpm}$, respectively, which was maintained when the microalgae were cultivated. These stress values are lower than those found by Hadiyanto et al. [16] in a simulation with CFD, who reported $\tau$ of up to $8 \mathrm{~Pa}$ with velocities of $0.6 \mathrm{~m} / \mathrm{s}$, which would cause greater cellular damage. Given that $\tau$ provides a significant contribution to cell damage, the values shown in Table 3 represent less damage compared to the values reported by Hadiyanto et al. [16]. 


\subsection{Effect of Stirring Speed on Microalgae Growth}

Hydrodynamic stress is a factor that has not been studied in Raceway bioreactors because it is considered so low that it can be neglected [31]. However, no study has been conducted to confirm this assumption. Figure 5 represents the growth curves of the microalgae consortium with the same culture medium but different stirring speeds. The growth difference is evident at $45 \mathrm{rpm}$ where the cell density increased more than six times. The increase in biomass measured in cell doublings at 35 and $40 \mathrm{rpm}$ is similar, 1.762 and 1.782 times, respectively, which corresponds to 570,417 , and 626,250 cells $/ \mathrm{mL}$ for each stirring speed. It is thought that this situation occurs due to the biomass quantification method, in which the number of cells present is counted, but the weight of biomass per unit volume is not determined since the microalgae have different sizes [32,33]. However, the graph (Figure 5) shows that agitation favors the growth of microalgae. This has already been observed by Kusmayadi et al. [34], who determined the growth of Chlorella vulgaris in a $20 \mathrm{~L}$ Raceway bioreactor at speeds of 13, 30, and $35 \mathrm{rpm}$, where they obtained 1.3, 1.8, and $1.85 \mathrm{~g} / \mathrm{L}$ of final biomass for each stirring speed. Poor agitation leads to poor mixing and results in poor oxygen removal during photosynthesis, which is counterproductive for microalgae as it slows the growth and accelerates cell death [4].

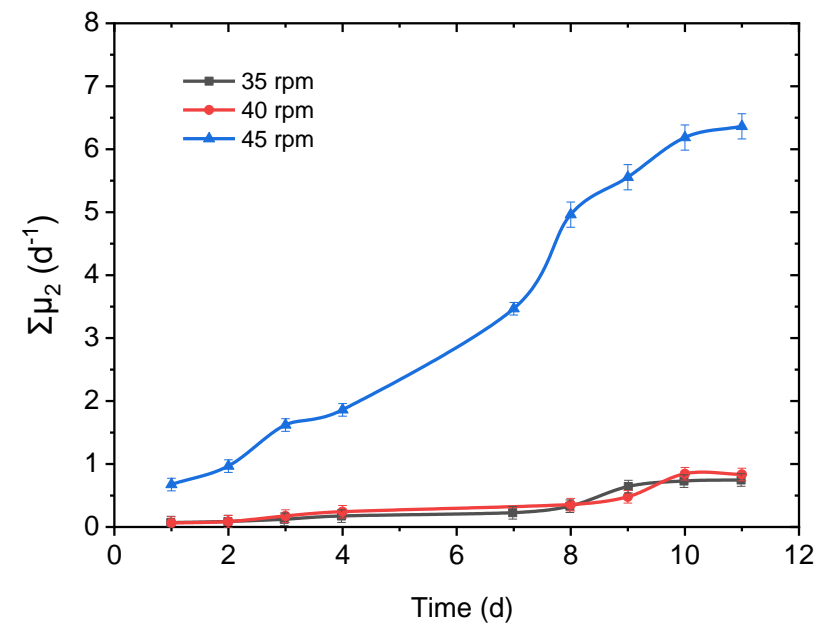

Figure 5. Comparison of consortium growth measured in the sum of cell duplications at 35, 40, and $45 \mathrm{rpm}$.

The literature shows that, as a microalgae culture develops, the flow rate is reduced due to the increase in cell density, making it difficult to maintain a homogeneous suspension. This increases the sedimentation of microalgae and the stagnation of the flow, so it is necessary to double the stirrer speed to maintain a flow speed of $0.30 \mathrm{~m} / \mathrm{s}$ [4]. Figure 6 shows the speed reduction as a function of the sum of the speed difference $\left(\sum \Delta v\right)$ with respect to the cultivation time of the microalgae. The data were processed from the beginning of the stationary phase of culture that corresponds to day 10 . The graph represents different speeds of agitation. The data indicate that, at $35 \mathrm{rpm}$, with an initial cell density of 323,750 cells $/ \mathrm{mL}$ and a final of 570,417 cells $/ \mathrm{mL}$, the flow velocity is 0.3913 and $0.3271 \mathrm{~m} / \mathrm{s}$, which implies a decrease of $16.41 \%$. At $40 \mathrm{rpm}$, the speed was reduced by $17.11 \%$; the initial speed was $0.4494 \mathrm{~m} / \mathrm{s}$, and it decreased to 0.3725 . In the two previous cases, the drop in speed presented a percentage difference of 0.7. However, at $45 \mathrm{rpm}$, the linear speed decreased by $20.13 \%$, starting at $0.4990 \mathrm{~m} / \mathrm{s}$ and ending at $0.3985 \mathrm{~m} / \mathrm{s}$. For the three stirring speeds, the speed reduction behaves linearly for the first three days (lag phase). The greatest effect on the decrease in speed occurs from the fourth day and up to the eighth (in the exponential phase) due to the increase in the number of cells. After day nine, the drop in speed began to slow down, which corresponds to a slower cell doubling (stationary phase). The velocity decrease curve can be used as an analogy to the growth curve of the microalgae consortium but in an inverted way. To maintain the same speed at the beginning 
and end of the culture, the angular speed must be adjusted and must be proportional to the cell density and its increase.

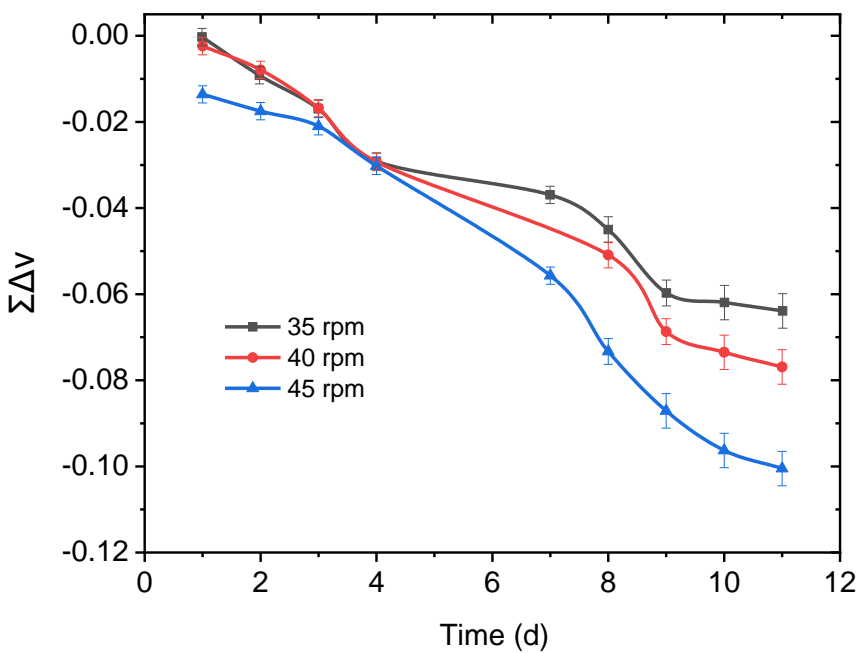

Figure 6. Representation of the decrease in speed with respect to the cultivation time of the microalgae consortium at different agitation speeds.

On the other hand, one of the effects of hydrodynamic stress on microorganisms is the change in the size of cell aggregates, causing microalgae to agglomerate to protect themselves [17]. This behavior was observed in the consortium under study. Figure 7 represents the evolution of the consortium at $35 \mathrm{rpm}$, where the cells agglomerated to form granules, where it is difficult to identify individual cells.
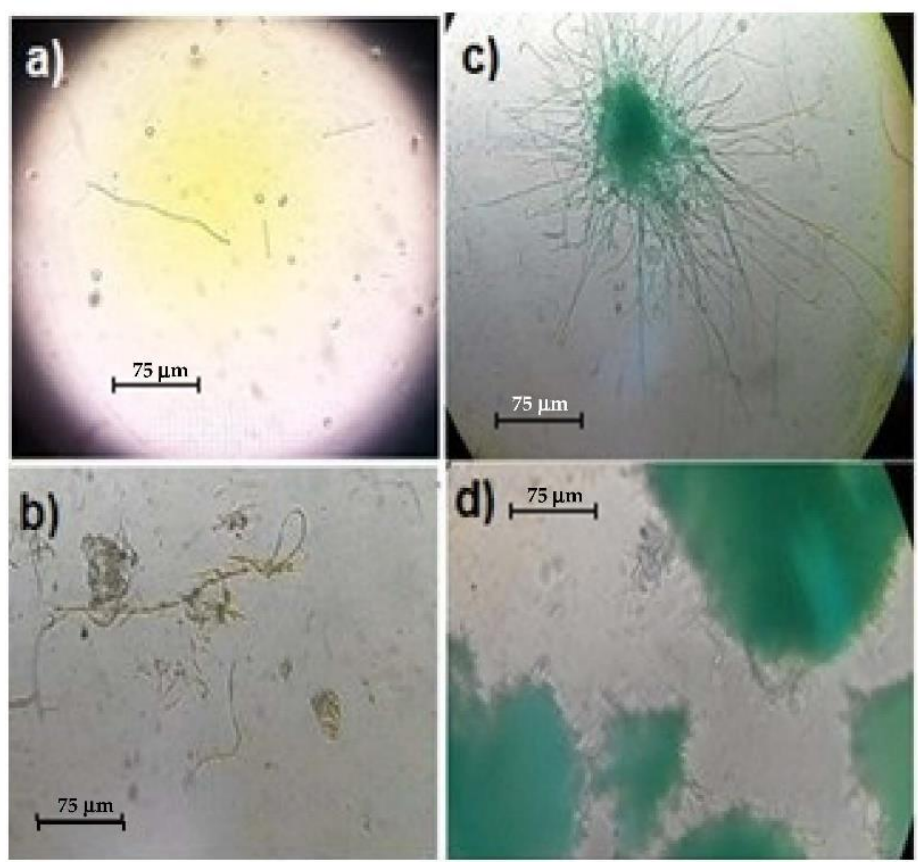

Figure 7. Formation of agglomerates of the microalgae at $35 \mathrm{rpm}$ : (a) first day of culture, the microalgae cells remain individual, (b) after three days of culture, the formation of agglomerates begins, (c) seven days of culture, evolution of agglomerates is evident; however, filamentous cells are still distinguished, and (d) 10 days of culture, agglomerates prevent individual cells from being identified. All the observations were done with $40 \times$ objective. 


\section{Conclusions}

The velocity profile of the microalgae culture broth decreases between $9-20 \%$ as the biomass concentration increases and the trajectories or flow profiles reached in the raceway. The criteria for a bioreactor scaling-up from $10 \mathrm{~L}$ to $100 \mathrm{~L}$ were the control of the $\mathrm{Re}$ and $\mathrm{Fr}$ dimensionless numbers and maintaining a corresponding velocity.

In a laboratory Raceway at different stirrer velocities (35, 40, and $45 \mathrm{rpm})$, the value of hydrodynamic stress $(\tau)$ determined by low-density PIV, shows that the hydrodynamic stress generated should not be neglected, as suggested by several authors. The average channel velocity can be mathematically established from the angular velocity with a high correlation $\left(\mathrm{r}^{2}=0.985\right)$. The behavior of the fluid velocity along the entire Raceway wall follows a gamma probability distribution, which makes it possible to associate bioreactor geometry with the agitator speed and calculate different sizes of Raceways.

Author Contributions: Conceptualization, A.C.-R. and S.S.B.-M.; methodology, S.S.B.-M., A.C.-R. and E.A.C.-U.; software, S.S.B.-M. and J.C.S.-R.; validation, A.G.-S., O.R.-N. and E.A.C.-U.; formal analysis, A.C.-R. and S.S.B.-M.; investigation, A.C.-R. and S.S.B.-M.; resources, C.A.G.-A., E.A.C.-U., R.O.-P., O.R.-N.; data curation, S.S.B.-M. and O.R.-N.; writing-original draft preparation, S.S.B.-M. and A.C.-R.; writing-review and editing, S.S.B.-M., A.G.-S. and A.C.-R.; visualization, E.A.C.-U.; supervision, R.O.-P. and O.R.-N.; project administration, A.C.-R.; funding acquisition, A.C.-R. and J.C.S.-R. All authors have read and agreed to the published version of the manuscript.

Funding: This research received no external funding.

Institutional Review Board Statement: This research received no specific grant from any funding agency in the public, commercial, or not-for-profit sectors. Not applicable.

Informed Consent Statement: Not applicable.

Data Availability Statement: Not applicable.

Acknowledgments: We thank Armando González Sanchez from the Engineering Institute of the UNAM, for the donation of the alkalophic microalgae consortium used in this study. The first author thanks the support to Consejo Nacional de Ciencia y Tecnología (CONACYT) for the scholarship granted to study the Doctorate degree in Biotechnology on the postgraduate program of Universidad Politécnica de Pachuca, included in the Programa Nacional de Posgrados de Calidad.

Conflicts of Interest: The authors declare no conflict of interest.

\section{References}

1. Michels, M.H.; van der Goot, A.J.; Norsker, N.-H.; Wijffels, R.H. Effects of shear stress on the microalgae Chaetoceros muelleri. Bioprocess Biosyst. Eng. 2010, 33, 921-927. [CrossRef]

2. Pires, J.C.; Alvim-Ferraz, M.C.; Artins, F.G. Photobioreactor design for microalgae production through computational fluid dynamics: A review. Renew. Sustain. Energy Rev. 2017, 79, 248-254. [CrossRef]

3. Slegers, P.M. Scenario Studies for Algae Production. Ph.D. Thesis, Wageningen University, Wageningen, the Netherlands, March 2014.

4. Chisti, Y. Large-Scale Production of algal biomass: Raceway ponds. In Algae Biotechnology. Green Energy and Technology; Bux, F., Chisti, Y., Eds.; Springer: Cham, Switzerland, 2016; pp. 21-40. [CrossRef]

5. Kanhaiya, K.; Sanjiv, M.; Anupama, S.; Min, S.P.; Won Yang, J. Recent trends in the mass cultivation of algae in raceway ponds. Renew. Sustain. Energy Rev. 2015, 51, 875-885. [CrossRef]

6. Slegers, P.M.; Lösing, M.B.; Wijiffels, R.H.; van Straten, G.; van Boxtel, A.J. Scenario evaluation of open pond microalgae productio. Algal. Res. 2013, 2, 358-368. [CrossRef]

7. Sompech, K.; Chisti, Y.; Srinophakun, T. Design of raceway ponds for producing microalgae. Biofuels 2012, 3, 387-397. [CrossRef]

8. Cadena-Ramírez, A.; Bautista-Monroy, S.S.; Monsalvo Licona, F.; Téllez Jurado, A.; Salgado Ramírez, J.C.; Gómez Aldapa, C.A. Dispositivo de Agitación Mécanica de Mezcla Completa y Bajo Consumo de Energía Para el Cultivo de Microorganismos Fotosintéticos. Mexican Patent No. MX2017011071, 7 May 2021. Instituto Mexicano de la Propiedad Industrial (Patent Office). Available online: https:/ / patentscope.wipo.int/search/es / detail.jsf?docId=MX242521807\&_cid=P12-KZ09M4-19990-1 (accessed on 10 January 2022).

9. Leupold, M.; Hindersin, S.; Gust, G.; Martín, K.; Hanelt, D. Influence of mixing and shear stress on Chlorella vulgaris, Scenedesmus obliquus, and Chlamydomonas reinhardtii. J. Appl. Phycol. 2013, 25, 485-495. [CrossRef] 
10. Scarsella, M.; Torzillo, G.; Cicci, A.; Belotti, G.; de Filippis, P.; Bravi, M. Mechanical stress tolerance of two microalgae. Process Biochem. 2012, 47, 1603-1611. [CrossRef]

11. Fadlallah, H.; Jarrahi, M.; Herbert, E.; Ferrari, R.; Mejean, A.; Peerhossaini, H. Effects of shear stress on the growth rate of microorganisms in agitated reactors. In Proceedings of the ASME 2016 Fluids Engineering Division Summer Meeting, FEDSM2016, Washington, DC, USA, 10-14 July 2016. [CrossRef]

12. Michels, M.H.; van der Goot, A.J.; Vermuë, M.H.; Wijffels, R.H. Cultivation of shear stress sensitive and tolerant microalgal species in a tubular photobioreactor equipped with a centrifugal pump. J. Appl. Phycol. 2016, 28, 53-62. [CrossRef]

13. Li, Y.; Zhang, Q.; Wang, Z.; Wu, X.; Cong, W. Evaluation of power consumption of paddle wheel in an open raceway pond. Bioprocess Biosyst. Eng. 2014, 37, 1325-1336. [CrossRef]

14. Zeng, F.; Huang, J.; Meng, C.; Zhu, F.; Chen, J.; Li, Y. Investigation on novel Raceway pondwith inclined paddle wheels through simulationand microalgae culture experiments. Bioprocess Biosyst. Eng. 2015, 39, 169-180. [CrossRef]

15. Bautista-Monroy, S.S.; Salgado-Ramírez, J.C.; Téllez-Jurado, A.; Ramírez-Vargas, M.D.R.; Gómez-Aldapa, C.A.; Pérez-Viveros, K.J.; Medina-Moreno, S.A.; Cadena-Ramírez, A. Hydrodynamic characterization in a raceway bioreactor with diferent stirrers. Rev. Mex. Ing. Quím. 2019, 18, 605-619. [CrossRef]

16. Hadiyanto, H.; Elmore, S.; Van Gerven, T.; Stankiewicz, A. Hydrodynamic evaluations in high rate algae pond (HRAP) design. Chem. Eng. J. 2013, 217, 231-239. [CrossRef]

17. Marín Palacio, L.D. El papel de la Potencia Volumétrica en la Producción y Glicolisación de Proteinas Recombinantes en Bacterias Filamentosas: APA (Proteínas de 45/47 KDa) de Mycobacterium Tuberculosis en Streptomyces Lividans. Ph.D. Thesis, Universidad Nacional Autónoma de México, Mexico City, Mexico, February 2016.

18. Mayorga, J.; Chávez, R.; Mayorga, O.; Delgado-Linares, J.; Sánchez, R.; Delgado-Linares, G. Escalamiento del reactor del proceso de coquización retardada. Cienc. Ing. 2014, 35, 147-155.

19. Ruiz Colorado, A.A. Factores de Escala para la Producción Biotecnológica de Etanol Carburante. Ph.D. Thesis, Universidad Nacional de Colombia, Facultad de Minas, Escuela de procesos y energía, Medellin, Colombia, March 2009.

20. Radmann, E.M.; Reinehr, C.O.; Costa, J.A. Optimization of the repeated batch cultivation of microalga Spirulina platensis in open raceway ponds. Aquaculture 2007, 265, 118-126. [CrossRef]

21. García Cruz, E.L. Thesis Evaluación del Crecimiento de Consorcio de Microalgas Alcalófilas en Fotobiorreactores con Potencial de Aplicación en el Enriquecimiento de Biogás. Facultad de Estudios Superiores Zaragoza, Institúto de Ingeniería, Mexico City, Mexico, 2015.

22. De los Cobos-Vasconcelos, D.; García-Cruz, E.L.; Franco-Morgado, M.; González-Sánchez, A. Short-term evaluation of the photosynthetic activity of an alkaliphilic microalgae consortium in a novel tubular closed photobioreactor. J. Appl. Phycol. 2016, 28, 795-802. [CrossRef]

23. Bermúdez, J.L.; Lodeiros, C.; Morales, E. Producción de biomasa de la microalga marina Chroomonas sp., en función del pH, intencidad luminosa y salinidad. Boletín Investig. Mar. Costeras 2002, 31, 167-185.

24. Ruiz, Á.A.; Álvarez, H. Escalamiento de Procesos Químicos y Bioquímicos basado en un Modelo Fenomenológico. Inf. Tecnol. 2011, 22, 33-52. [CrossRef]

25. Muñoz Equihua, E.S. Escalamiento del Proceso de Obtención de Fructooligosacáridos a Partir de Jugo de Caña Mediante Síntesis Enzimática con Células Permeabilizadas de Candida Apicola. Master's Thesis, Centro de Investigación y Asistencia en Tecnología y Diseño del Estado de Jalisco, Guadalajara, Mexico, June 2016.

26. Garcia-Ochoa, F.; Gomez, E. Bioreactor scale-up and oxygen transfer rate in microbial processes: An overview. Biotech. Adv. 2009, 27, 153-176. [CrossRef]

27. Chiaramonti, D.; Prussi, M.; Casini, D.; Tredici, M.R.; Basi, N.; Chini Zittelli, G.; Bondioli, P. Review of energy balance in raceway ponds for microalgae cultivation: Re-thinking a traditional system is possible. Appl. Energ. 2013, 102, 101-111. [CrossRef]

28. Escobar Parra, S. Estudio del Transporte y Consumo de Oxígeno en Cultivos Bacterianos: Estrés Hidrodinámico. Ph.D. Thesis, Universidad complutense de Madrid, Facultad de ciencias químicas, Departamento de Ingeniería Química Madrid, Madrid, Spain, 2014.

29. García-Ochoa, F.; Gomez, E.; Alcon, A.; Santos, V.E. The effect of hydrodynamic stress on the growth of Xanthomonas campestris cultures in a stirred and sparged tank bioreactor. Bioprocess. Biosyst. Eng. 2012, 36, 911-925. [CrossRef]

30. Mazzuca Sobczuk, T. Influencia de las Condiciones Hidrodinámicas y de la Fracción Molar de $\mathrm{CO}_{2}$ en la Fase Gaseosa Sobre el Crecimiento Celular en Cultivos de Microalgas. Ph.D. Thesis, Universidad de Almeria, Almeria, Spain, 2003.

31. Olivero Novillo, M.L.; Aguirre Pe, J. Esfuerzo de corte en canales lisos. Ing. Hidraul. Mex. 2001, 16, 39-45.

32. Wang, C.; Land, C.Q. Effects of shear stress on microalgae-A review. Biotechnol. Adv. 2018, 36, 986-1002. [CrossRef]

33. Dimar-CIOH. Catálogo de Fitoplancton de la Bahía de Cartagena, Bahía Portete y Agua de Lastre; Dirección General Marítima-Centro de Investigaciones Oceanográficas e Hidrográficas del Caribe, Ed Dimar, Serie de Publicaciones Especiales CIOH: Cartagena de Indias, Colombia, 2011; Volume 5, p. 135.

34. Guamán Burneo, M.C.; González Romero, N.P. Catálogo de Microalagas y Cianobacterias de Agua Dulce del Ecuador; Corporación para la Investigación Energética, Laboratorio de Biotecnología Energética: Quito, Ecuador, 2016; p. 122. ISBN 978-9942-14-874-2. 